\begin{tabular}{|c|c|c|c|c|c|c|c|c|c|}
\hline \multirow[b]{2}{*}{ Source } & \multicolumn{9}{|c|}{ High risk groups } \\
\hline & $\begin{array}{l}\text { People with family } \\
\text { history of coronary } \\
\text { heart disease }\end{array}$ & $\begin{array}{c}\text { People with } \\
\text { family history of } \\
\text { hyperlipidaemia }\end{array}$ & $\begin{array}{l}\text { People with } \\
\text { personal history } \\
\text { of coronary } \\
\text { heart disease }\end{array}$ & $\begin{array}{c}\text { People with } \\
\text { physical signs of } \\
\text { hyperlipidaemia- } \\
\text { for example, arcus } \\
\text { xanthoma, } \\
\text { xanthelasma }\end{array}$ & $\begin{array}{c}\text { People with } \\
\text { hypertension }\end{array}$ & Diabetics & $\begin{array}{l}\text { Obese } \\
\text { people }\end{array}$ & $\begin{array}{l}\text { People with } \\
\text { a history } \\
\text { of gout }\end{array}$ & Smokers \\
\hline $\begin{array}{l}\text { Study group of the European Atherosclerosis } \\
\text { Society, } 1987\end{array}$ & $\begin{array}{l}\text { Yes, especially if } \\
\text { history is in relative } \\
<50\end{array}$ & Yes & & Yes (specified) & Yes & Yes & Yes & Y'es & Yes \\
\hline $\begin{array}{l}\text { Coronary Prevention Group, } 1987 \\
\text { fournal of the Royal College of General }\end{array}$ & Yes, (age unspecified) & Yes & Yes & Yes (specified) & Yes & Yes & & & \\
\hline & Yes if patient is $<60$ & & Yes & & Yes & Yes & & & Possibly \\
\hline $\begin{array}{l}\text { Practitioners (editorial) } 1988 \\
\text { Royal College of General Practitioners, } 1988\end{array}$ & $\begin{array}{l}\text { Yes (age unspecified) } \\
\text { Yes if history is in } \\
\text { relative }<60\end{array}$ & Yes & $\begin{array}{l}\text { Yes } \\
\text { Yes }\end{array}$ & $\begin{array}{l}\text { Yes (specified) } \\
\text { Yes (specified) }\end{array}$ & Y'es & $\begin{array}{l}\text { Yes } \\
\text { Yes }\end{array}$ & Yes (gross) & & \\
\hline Drugs and Therapeutics Bulletin, 1987 & $\begin{array}{l}\text { Yes, especially if } \\
\text { history is in relative } \\
<50\end{array}$ & Yes & & Yes (specified) & Yes & Yes' & Yes & & \\
\hline
\end{tabular}

of action for their patients. Apart from financial considerations screening for raised cholesterol concentrations is not without problems. People with positive results may become anxious whereas those with negative results may be reassured falsely and fail to make important changes in lifestyle. ${ }^{1+}$ In addition, a person's cholesterol concentration may vary from time to time, ${ }^{15}$ leading to misclassification. Tunstall-Pedoe et al showed recently that one dimensional algorithms with fixed cut off points between normal and abnormal cholesterol concentrations and universal management protocols are inappropriate in the United Kingdom as they fail to take into account sex differences and the fact that cholesterol concentration rises with age. ${ }^{16}$

Population and high risk strategies are said commonly to be complementary rather than alternative approaches to preventing coronary heart disease. Though this is true, different emphasis given to one or other strategy can be expected to lead to different consequences in terms of both use of resources and eventual impact on the disease. A British consensus is needed urgently to determine priorities and policies concerning measurement of cholesterol concentrations and treatment. In the mean time general practitioners may choose to measure cholesterol concentrations only in people with a high risk of coronary heart disease and concentrate their efforts on identifying and treating as many people in this category as possible until an agreed national policy emerges.

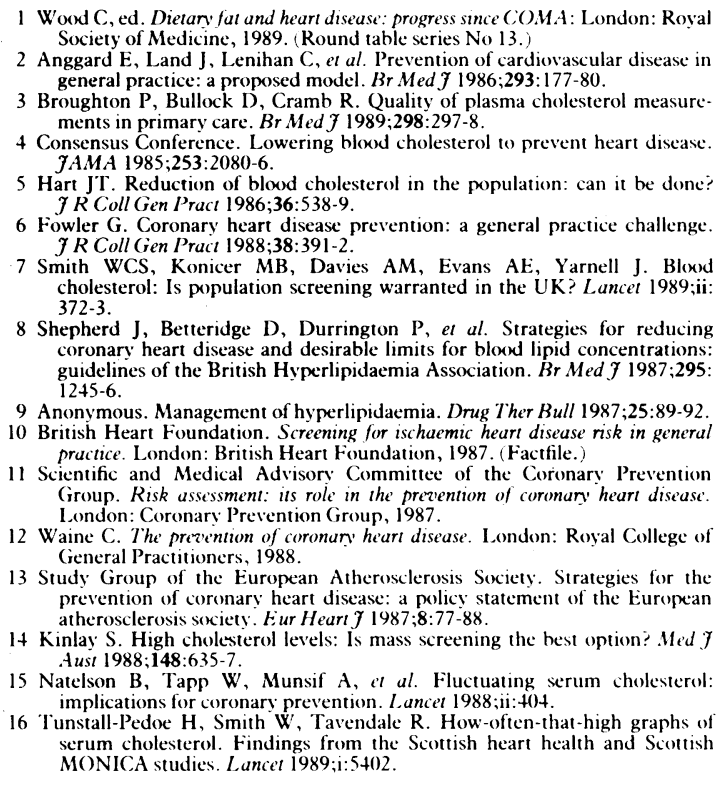

Society of Medicine, 1989. (Round table series No 13. ments in primary care. Br Med $\mathcal{F}$ 1989;298:297-8.

It $\mathrm{JT}$. Reduction of blood cholese

egies for reducin conary heart disease and desirable limits for blood lipid concentration

. . Fundation. Screening for ischaemic heart disease risk in general

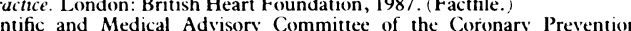

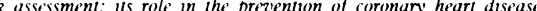

Waine $\mathrm{C}$. The prevention of coronan heart disease. London: Royal College of hest options thed implications for coronary prevention. L ancet 1988;11:+04. serum cholesterol. Findings from the Scottish heart health and Scottis

(Accepled 18.May 1989
University Department of Medicine, Bristol Royal Infirmary, Bristol BS2 8HW Luke J D O'Donnell, MD, medical registrar

Pauline M Emmett, BSC, dietitian

Kenneth W Heaton, FRCP, reader in medicine

Correspondence to: $\mathrm{Dr}$ Heaton.

BrMed F 1989;298: 1616-7

\section{Size of flour particles and its relation to glycaemia, insulinaemia, and colonic disease}

\section{Luke J D O'Donnell, Pauline M Emmett, Kenneth W Heaton}

The rise in plasma insulin concentration after a meal varies with the digestibility of the starch consumed.' If digestion is incomplete starch escapes into the colon and has an effect similar to that of dietary fibre. Several Western diseases are partly attributed to hyperinsulinaemia (hypertension, obesity, gall stones, atherosclerosis ${ }^{2}$ ) and to overefficient digestion of starch (diverticulosis coli and colonic neoplasia). ${ }^{3}$ One determinant of the digestibility of food, particularly cereals, is the size of the particles. As much of the starch in Western diets is provided by bread made from finely milled flour it might be beneficial to eat less digestible bread made from coarse flour. Plasma insulin concentrations might rise less and more starch might escape from the small intestine after a meal containing bread made from coarse flour. To test this hypothesis we studied people with permanent ileostomies as well as non-insulin dependent diabetics.

\section{Patients, methods, and results}

We studied nine healthy, non-obese patients with ileostomies (aged 30-69; four men) who had had a curative total proctocolectomy for ulcerative colitis, and 11 non-insulin dependent diabetics (aged 44-68; six men). The diabetics were receiving oral hypoglycaemic drugs: mean body mass index and glycated haemoglobin concentration were 28.5 (range 21.6$36.9) \mathrm{kg} / \mathrm{m}^{2}$ and $9.93(7 \cdot 6-11 \cdot 9) \%$ respectively.

Coarse and fine wholemeal flours were milled from the same batch of English wheat. None of the fine flour but $40 \%$ of the coarse flour was retained by a sieve with $1 \mathrm{~mm}$ holes; $20 \%$ of the fine flour but $80-85 \%$ of the coarse flour was retained by a sieve with $140 \mu \mathrm{m}$ holes.

Test breakfasts (containing $52.4 \mathrm{~g}$ carbohydrate) consisted of sodabread scones made from $76 \mathrm{~g}$ fine or 
Mean (SEM) areas under glucose and insulin curves a fter mixed meals containing bread made with fine and coarse wholemeal flour in healthv patients with ileostomies and non-insulin dependent diabetics

\begin{tabular}{|c|c|c|c|c|}
\hline & \multicolumn{2}{|c|}{ Area under glucose curve $(\mathrm{mmol} / \mathrm{l} \cdot \mathrm{min})$} & \multicolumn{2}{|c|}{ Area under insulin curve ( $\mathrm{mU} / \mathrm{l} \cdot \mathrm{min})$} \\
\hline & Fine flour & Coarse flour & Fine flour & Coarse flour \\
\hline Healthy patients with ileostomies & $141(27)$ & $93(17)$ & $3992(442)$ & $3095(228)$ \\
\hline Mean paired difference & \multirow{2}{*}{\multicolumn{2}{|c|}{$\begin{array}{c}48 \\
-9 \text { to } 104\end{array}$}} & \multirow{2}{*}{\multicolumn{2}{|c|}{$\begin{array}{c}898 \\
16 \text { to } 1779\end{array}$}} \\
\hline $95 \%$ Confidence interval & & & & \\
\hline Non-insulin dependent diabetics & $683(78)$ & $553(54)$ & $4157(534)$ & $3397(476)$ \\
\hline Mean paired difference & \multicolumn{2}{|c|}{$\begin{array}{c}130 \\
9 \text { to } 25\end{array}$} & \multicolumn{2}{|c|}{$\begin{array}{c}760 \\
364 \text { to } 1155\end{array}$} \\
\hline
\end{tabular}
coarsely milled wholemeal flour mixed with $0.75 \mathrm{~g}$ water and baked at $210^{\circ} \mathrm{C}$ for 15 minutes and eaten with $21 \mathrm{~g}$ Cheddar cheese, $8 \mathrm{~g}$ butter, $300 \mathrm{ml}$ tea, and $50 \mathrm{ml}$ milk. All subjects ate the two breakfasts in random order seven days apart after a 12 hour fast. The patients with ileostomies received snacks free of starch three and five and a half hours after the breakfasts. Venous blood samples were taken during the fasting period and at $1020,30,40,50,60,75,90,120,150$, and 180 minutes after the beginning of the test meal. A sample was also taken at 240 minutes for the diabetics. In one patient with an ileostomy venous access was not possible. Plasma insulin and glucose concentrations were assayed by standard methods.' The areas under the postprandial concentration curves were calculated as those above the fasting concentrations. Effluent from the ileostomies was collected for eight hours after the meal and stored at $-20^{\circ} \mathrm{C}$. Effluent starch was measured with amyloglucosidase. ${ }^{+}$Significance was determined by Student's $t$ test.

In both groups the meal containing bread made from coarse flour resulted in lower plasma glucose and insulin concentrations than that containing bread made from fine flour (table). Unabsorbed starch was $42 \%$ higher after the meal made from coarse flour (mean (SEM) 563 (86) v 397 (55) mg; mean difference $167 \mathrm{mg}, 95 \%$ confidence interval 50 to $284 \mathrm{mg}$ ).

\section{Comment}

We found that breads made from coarse and fine flour have different effects in middle aged people and in non-insulin dependent diabetics as well as in young people,' even when the bread is part of a mixed meal. Coarse flour evokes less insulinaemia, which suggests that if regularly consumed it might decrease the risk of hypertension, atherosclerosis, gall stones, and obesity. It also allows more starch to escape from the small intestine. Thus the risk of some colonic diseases, including cancer, might be reduced if coarse flour was eaten regularly and combined with other less completely digested starchy foods.

Diabetics are recommended to add cracked or whole grains to their bread to reduce glycaemia. ${ }^{5}$ Our data show that there is a simpler alternative, and we suggest that eating bread made from coarsely milled flour might improve diabetic control if bread forms a substantial proportion of the daily food intake.

We thank Dr Simon Hook of the Flour Millers and Bakers Research Association for providing flour, Bristol and Weston District Medical Research Committee for financial help, Dr R J M Corrall and Miss A Moffatt.

1 Heaton $\mathrm{KW}^{\prime}$, Marcus SN, Emmett PM, Bolton $\mathrm{CH}$. Particle size of wheat, maize and oat test meals: effects on plasma glucose and insulin responses and on the rate of starch digestion in vitro. Am f Clin Nutr 1988;47:675-82.

2 Stout RW. Insulin and atheroma - an update. Lancet 1987;i:1077-9.

3 Thornton JR, Dryden A, Kelleher J, Losowsky MS. Super-efficient starch absorption. A risk factor for colonic neoplasia? Dig Dis $S c i$ 1987;32: 1088-91 + Chapman RW, Sillery JK, Graham MM, Saunders DR. Absorption of starch by healthy ileostomates: effect of transit time and carbohydrate load. $\mathrm{Am} \mathrm{f} \mathrm{Cln}$ Nutr 1985;41:1244-8.

5 Jenkins DJA, Wesson V, Wolever TMS, et al. Wholemeal versus wholegrain breads: proportion of whole or cracked grains and the glycaemic response. Br.Med J 1988;297:958-60.

(Accepted 8 March 1989)

\section{Role of infant feeding practices in development of Crohn's disease in childhood}

\section{S Koletzko, P Sherman, M Corey, A Griffiths, C Smith}

Division of

Gastroenterology,

Departments of Pediatrics and Nursing, Research

Institute, Hospital for Sick

Children, University of

Toronto, Toronto, Canada

M5G 1X8

$\mathrm{S}$ Koletzko, MD, research

fellow

P Sherman, MD, assistant

professor

M Corey, MSC, statistician

A Griffiths, MD, assistant

professor

C Smith, RN, gastroenterology

nurse

Correspondence to: $\mathrm{Dr}$

Sherman.

BrMed f 1989;298:1617-8
One hypothesis on the aetiology of Crohn's disease suggests that environmental factors initiate intestinal inflammation in genetically susceptible people. To determine the effects of breast feeding on the subsequent development of the disease we examined practices of infant feeding among affected children and unaffected siblings.

\section{Patients, methods, and results}

We sent a questionnaire to 145 families with at least one child aged under 18 with Crohn's disease that had been established by radiological, endoscopic, and histological criteria. The study was approved by the hospital's human subject review committee.

We used Student's $t$ test to compare mean values, a conditional logistic regression model to analyse potential risk factors for the disease within families in which unaffected siblings were available as controls, and an SAS computer program' to analyse matched data with a variable number of cases and controls.

Of 145 families, $128(88 \%)$ with a total of 325 children completed the questionnaires. Adopted children, half siblings, and 23 children with the disease but without an unaffected sibling were excluded. The remaining 114 patients and their 180 unaffected siblings from 107 families comprised the study group. Over half $(56 \%)$ of the children with Crohn's disease were boys, but this proportion was not significantly different from that in unaffected siblings $(50 \%)$. Although the median age in the two groups was similar (Crohn's disease $15 \cdot 7$ years; siblings $17 \cdot 2$ years), the mean (SD) age of the children with the disease was lower $(16 \cdot 1(3 \cdot 2)$ years $v 18 \cdot 1(7 \cdot 6)$ years, $\mathrm{p}<0 \cdot 01)$. Birth order and month of birth showed the same distributions among patients and controls.

Analysis of potential risk factors showed that patients were less likely to have been breast fed (relative risk $3 \cdot 6,95 \%$ confidence interval $1 \cdot 4$ to $9 \cdot 0, p<0 \cdot 01$ ), more likely to have received formula food from birth $(3 \cdot 1$, 1.3 to $7 \cdot 4, p<0.02$ ), and more likely to have had diarrhoeal illnesses during infancy $(2.7,1.5$ to 5.8 , $\mathrm{p}<0.02)$. Sex, premature delivery, type of milk used for bottle feeding, age at introduction of solid foods, and length of exclusive and total length of breast feeding did not differ between patients and controls.

Multivariate analyses showed that only two factorslack of breast feeding and episodes of diarrhoeal disease during infancy - were independently associated with later development of Crohn's disease (table). The interdependence of breast feeding and formula feeding was shown by a reduction in the significance of breast feeding in the three variable model and by the significance of formula feeding when it was combined 